\title{
Pauline McLeod: The Magpie who became a Swan - finding salvation in culture
}

\section{Simon Luckhurst}

Pauline McLeod was an Aboriginal performer, writer and storyteller who, at the time of her death at the age of 43 in 2003, left an archive of 34 boxes of writing: poems, diaries, notes, playscripts, film ideas and letters. Amongst the completed scripts and story drafts were also many examples of jotted notes and ideas, phrases and paragraphs, mostly undated. Also amidst the ephemera of her life were bus tickets, electricity bills and birthday cards, as well as a few letters, reports and reviews pertaining to Pauline but authored by other people. After she died her brothers cleared her flat, packing her things into the boxes. They were hoping that someone would use this material to tell Pauline's life story, and after being contacted by a mutual friend I have now spent some time working on the project.

It is my intention to use only material found in the boxes to tell Pauline's life story. To complete this process I have been literally 'unpacking' Pauline's work, scanning anything I think could be included in a biographical construct.

The story that will emerge will describe how she was fostered and later adopted, what life in her adopting family was like, how she met her natural family and how her adopting family disowned her after this took place. It will also cover her subsequent battle with mental illness which sometimes left her institutionalised, as well as her discovery of Aboriginal culture. I intend to explore how she came to rely on these experiences both for strength and for her career as a storyteller and writer.

In this paper I will describe some of these facets of Pauline's life, as well as attempting a brief discussion of some of the theoretical aspects I have been exploring as part of the compilation process.

\section{The material}

Given the possible reasons Pauline had for writing, and the likelihood of omissions of other aspects relevant to her 'complete' life story, it is appropriate that potential readers be given information on the nature of the text in advance of their reading it so they understand that they do not have the 'complete' version of something that was not complete in the first place. It is important, too, that the reader knows something of me - at a minimum, that I am male and non-Indigenous. They should know how I came to the project, the length of 
time I worked on it and what I hope will be the final result. They should understand my arrangement of Pauline's life, and that it is my attempt to convey what I understand to be the meaning of her words. My hope is that the presented life is recognisable to those who remember her, yet is also capable of offering new insights.

Pauline was born in March 1960 and wrote throughout her life. She kept much of her work, with the earliest surviving piece appearing to be a diary written in early 1976. The following extract is from the 1976 diary, New Years Day.

We came home today after a week at our cousin's place. Last night we stayed up till 2 o'clock. It was fun. We had a little party and music. At 9 o' clock we started home and at 3 we reached home. It was hot and we went to sleep as soon as our jobs were done. Our TV broke. Pappa is going to try and get it fixed. My Bible verse for today:

Our Lord and our God. With joy in thee. Without, Thy heir we could not face unafraid the year before us.

God, please help me. Amen. ${ }^{1}$

As well as journals Pauline also wrote plays, poems, stories, letters and notes, while keeping miscellaneous other items including drawings, sketches, cartoons and photographs. The challenge for me in assembling this material is to create a cohesive narrative from the fragments, to let Pauline tell 'her own story' but in a myriad of forms, to allow the whole to become clear from the sum of many parts. I am still transcribing the material to be included in Pauline's story. Having read through all the documents I have found that there is enough to give a thorough account of her life, told in her own words, or through words that Pauline herself collected, either as letters written to her or as reviews. The challenge is how to determine not only what to include, but in what order to place the chosen extracts. In total there are over 3500 pages of documents, far more than most people wanting to find out about Pauline would be willing to sift through if left unedited. My intention is to construct a familiar autobiographical-type life story, with a beginning, middle and end. ${ }^{2}$ This will require a solid period of assembly, as well as some editing to create a satisfactory narrative structure. While the cultural and gender-related content of this story requires discussion outside the scope of this paper, it is appropriate to here discuss some aspects of the editorial process used to create the story.

What Pauline wrote in her diaries was probably not intended for verbatim reproduction. It is arguable whether her creative work, too, would have undergone some sort of editorial process prior to publication. Although there are arguments against editorial intervention of Indigenous texts, including 'gubbarising' ${ }^{3}$ it, I have taken the approach that this process is, to some degree, a valid methodology for the kind of story I am creating in this case. In his book, 
A shared authority, Michael Frisch argues that if necessary, the process of editing material obtained from oral history can sometimes require 'a relatively aggressive, even manipulative approach to the "actual" text (being) the best way to faithfully convey its real meaning and essence' . ${ }^{4}$ While Pauline's work is not oral history, I feel that some editorial intervention is appropriate to present her story to an audience unfamiliar with her life and writing.

Pauline's papers are a unique glimpse into her own experiences, much of them written as diary entries. In examining her journals, Pauline made the following notes:

Notes on Diary and Journal Writing from 'The New Diary' ${ }^{5}$

Diary uses:

Developing creativity

Problem solving

Self discovery

Self reliance and self help 6

Like many diaries and other works written in the form of a journal there is no indication that what remains is indeed an accurate reflection of the life. Indeed, if the criteria above represent how Pauline saw her diary writing, then it is possible to conceive of her diaries as material created only when she needed to develop her creativity, had a problem to solve, was looking inwardly or was suffering from self-doubt. The weighting of particular accounts also deserves examination. What, for example, are we to make of the fact that Pauline mentioned her personal relationships so infrequently, and then almost flippantly? The absence of a serious examination of something most people consider important to their lives demands its own interpretation.

\section{Some significant events in Pauline's life}

Pauline was removed from her natural family when she was two years old, and she often repeated the story of how her mother went for help to the 'welfare' to find food and accommodation for herself and her six children. Instead she had all her children removed from her and was not to see her family again for more than two decades. Pauline was initially placed in a children's home before being fostered to a German family when she was four. She then moved with them to the mid-north coast of New South Wales, where she began to attend school.

The following extract is from Pauline's play, The stolen one, in which the central character, June, appears to experience some of things that Pauline herself underwent:

June is now depicted as a child of six, wearing white stockings, carrying a skipping rope with her arm heavily bandaged. 
June: I wish I could play, but they would laugh, make fun of me all da time. I don't know why. I am a good girl, I am. (June looks guilty.) But I had to hit Martin Farrell, cos he said I eat widd... widdgidy grwads. ${ }^{7}$ (Pause.) I don't. He make me so mad. I hit him real hard. Like so. (She demonstrates.) He should have fall down, but he didn't. So I hit him again, like so. (She demonstrates a more powerful punch.) He still wouldn't fall down, so I told Mr Jamerson ... He gave me and Martin Farrell the cane! Why dey laff at me? I wish I could wash it off with soap or water or something. ${ }^{8}$

The family matriarch was 'Mutti', a strong-willed German woman who had taken it upon herself to raise six Aboriginal children as a promise to God. (She believed He had saved her life when she was ill.) In an unnamed story, Pauline wrote:

Being the eldest in our large family meant that I had little time or space to myself. When the chance came I always took it. Like when I had to look for a missing cow in the bush paddock ... It was during one of those times I was alone in the bush. I couldn't hear anyone. I was by myself, with no responsibility for anyone else except me. I loved those times. I started to explore, and during my exploration I started to have an adventure. Like I was in the darkest part of Africa, where there could be danger at every turn. At anytime a crazed wild animal might come charging towards me. Then, as I jumped over a fallen tree, I came across a little glen. It took my breath away. It was the most beautiful sight I had ever seen. A sunbeam lit up a small area near a crystal clear creek. The grass looked like it had been mowed. It was as if I was in the front yard of some little pixies or fairies, some little spirits who lived there. I had found a special, magic place. I lay down in the sunlight and for a second I even thought I had seen one of the pixies running behind some rocks. It was peaceful, warm and comfortable. And I forgot all the sorts of problems a twelve-year old girl might have had. ${ }^{9}$

The sorts of problems a 12-year-old girl might experience had sadly gone beyond even those of someone removed from their natural family. As well as Mutti's strict discipline, something more sinister was occurring, not noted by the Department of Youth and Community Services officers who came regularly to check on the family.

The foster family and the children that comprise the family are a very close unit. The parents are of German descent having come to Australia 22 years ago and since that period of time have been very keen on getting and caring for state wards, in particular Aboriginal state wards. The strangest facet of this foster placement is the ability of these foster parents to instil a family life atmosphere into all of the children in their care and 
to work so successfully with a wide age range of children of aboriginal descent. Pauline is extremely happy in this setting basically because she has foster parents who have reasonable expectations and are very geared to the problems that this girl has. She is also very secure and happy to the fact that she is with other state wards of Aboriginal descent. ${ }^{10}$

Pauline later wrote more extensively on the reality of her life at the time:

As we grew older and started to develop sexually I remember that my foster sister and I would be in the bathroom and often we would see eyes looking at us through windows or keyholes or holes in the walls. $\mathrm{Mr}$ Flory was watching us. I know this as a fact as he called out as we tried to cover the holes. We became very anxious and guarded about even undressing ourselves or being naked in our bedroom, as we on occasion could see someone outside looking in. We mentioned to Mrs Flory what was happening. She told us not to be promiscuous. Our foster brothers started to do as Mr Flory was doing, such as looking into the bathroom and bedroom. We had no privacy at all. My foster sister and I became ashamed of our bodies and could not even undress or change in front of each other. Whenever the welfare department officers attended the Flory's home, not one of us children was ever allowed to be alone with the department officers. Mr and Mrs Flory made certain that we were always supervised by them during any Departmental visits. Both $\mathrm{Mr}$ and Mrs Flory scared us. One of the punishments Mrs Flory used on us was to put the person to be punished in the centre of a circle and made the other children gang up on that person. It was a form of divide and conquer. Even if you didn't agree with it you still had to take part in it. $^{11}$

On leaving school, Pauline attended Technical College, then worked as an enrolled nurse before joining the NSW Department of Youth and Community Services. Here she became a District Officer, one of the first Aboriginal people to do so. It was in this capacity that she was able to view her own ward file. She wanted to meet her natural family, but had fears she might lose her foster family in the process. She told the story in her play:

June: I wonder what my natural parents are like. I am going to meet them one day, not just yet though. Mother and Father would flip. I can talk to them about anything except my natural family, or how I feel about them and miss them. Father already says I am ungrateful for what they done for me when he is angry with me. I already lost one family. I couldn't lose another one. ${ }^{12}$ 
Despite the fear, the desire to know her family remained strong. Her eventual reunion with her mother, sister and three brothers in 1986 generated many conflicting emotions for Pauline. Her diary records:

The experience was brilliant. For the first time I belonged somewhere. I really fitted in. I learnt about my history. I met my mother and family. I met aunties, uncles, cousins and other relatives beyond my wildest dreams. I was scared of not belonging, of rejection. Of losing.

After the reunion I started getting lost in a maze of grief, hurt, pain. I was confused. The dream became a nightmare, I was slowly drowning in depression, suicide and despair. The loss became too great and for a period I wandered, looking for answers that no-one had. ${ }^{13}$

Pauline did not initially tell Mutti and Pappa she had met her natural mother, but wanted to be honest with them and to let them know what she was going through. This traumatic experience later recreated in a dialogue form:

Mutti/ Pappa: You never told us.

Pauline: I had to do this one thing on my own, and I am telling you now.

Mutti/ Pappa: You went behind our back and did this. Why? What did we do wrong to deserve this treatment from you?

Pauline: I didn't do this to deliberately hurt you. They are my natural family. I just wanted to meet them.

Mutti/ Pappa: You betrayed us. It wasn't them who sat up all night when you were sick. Or kissed you better when you hurt yourself. Of fed you or clothed you for all these years. They didn't encourage you to get where you are today. ${ }^{14}$

Sadly, Pauline's natural mother died within a year of their meeting. Her death was followed a few months later by that of her brother, Robert. Her mother's death she portrayed in verse

I loved her straight away

She had no anger or hatred

Only peace and wisdom.

A gentle kind woman

Whose patience paid off

She got to see her grown children

And her four granddaughters too!

Now her journey's over

She can rest at last

She showed in the end

That love would win. ${ }^{15}$ 
By this time Pauline had resigned from her job as a Welfare Officer and left Dubbo. She moved to Sydney, where she continued to suffer from depression, and in 1988 admitted herself to Prince Henry Hospital's psychiatric ward. It was not the only time she found herself there, for after she discharged herself her mood swings and depression continued. Her diary notes:

Still feeling down. I am feeling very lonely. I know it's not good to sit in my flat by myself, but how often do people want me at their places. If I had a gun I'd probably ... No, I wouldn't. I mean, I think of it all the time. Different methods and plans, but when it comes to the brass tacks, I couldn't go ahead. I'd be scared shitless I'd get caught. Last night, for example, I thought, 'why not empty that last lot of pills I have', but then I thought, 'No. Forget it'. At this point I don't want to die. Maybe sleep, but not die. It takes forever for the sun to rise, 5 to 6 am is a long, slow time to wait. Cry, you jerk, just cry! ${ }^{16}$

For Pauline the pain and angst of her situation continued through the subsequent years to the early 1990s. The following passage, extracted from a letter draft probably never sent, is by no means unusual in its depiction of the grief she felt during this period.

Pauline Elizabeth McLeod died last night. She no longer is. Her body is breathing. She eats and sleeps. She continues on as if all is well, keeping up the pretence of life. Pauline Elisa Flory is dead. She died last year, when Mutti looked her in the eye and told her she was no longer her daughter. Both Paulines are dead. What is left? A shell of her former self, an image that will soon die. But not alone ... no, not alone. Why can't they help? Why don't they try? Why haven't things changed? I feel like a walking time bomb that is due to explode very soon. Nothing and no-one can stop me. I have tried. Dear GOD, I have tried. I went for help, but there is nothing there. These arses don't know what the fuck is going on, and she doesn't know how to tell them. She is a boiling pit of anger, and soon she will show them all the extent of her pain. A silent sufferer will start to talk, and spill like a psycho. Nothing can touch her. Nothing will. She lies awake waiting for the right trigger to be pushed. It's coming. Slowly she can see it, and once it hits, it will do so with much vengeance and destruction. No-one will be able to contain her, or stop it. ${ }^{17}$

Pauline blamed many people for her situation, including herself. Mostly, though, it was the government or her foster family to whom she directed her anger. Her diary:

I wonder if it's wrong to kill people? Mutti and Pappa are number one on my hit list. I feel they have cursed me and my family. The very first 
time I told them about meeting my family, Mutti came out and asked me what I called her, my mother. I was honest and told her, 'I call her Mum.' In an instant I saw all of Mutti's hate and hurt. She hated Mum and I had hurt her. I figure it was then that she cursed me. I don't know why GOD listened and granted her wish, but tell you what, it's very unfair and the only way to stop all of this, is to kill them. It'll reverse the curse. Once I buy the gun I'll have enough ammo to destroy them all. Make me look like a fool, will they? Treat me like shit? Fuck them all. ${ }^{18}$

Sometimes it was expressed more simply:

Knock knock.

Who's there?

Madness.

Madness who?

You! $!^{19}$

Pauline's diaries show a range of emotions. There were pages of plans, while others described her wretched unhappiness, her pleas to her foster family to take her back in, ${ }^{20}$ and the times when it became apparent that it had all become too much, and when even her writing offered no solace.

Nor was her relationship with her natural family as smooth as she had hoped. Her father had died long before the reunion, her two surviving brothers and one sister had all undergone some form of trauma following their own removal. All were now coping with the repercussions of this in their own ways and sometimes they were not able to provide Pauline with the support she wanted. Possibly no-one could have done so.

After the reunion, Pauline heard a story which was to change her life which, at different times, she said was told to her both by her mother and her brother, Rick. It was the story of how the kangaroo got its pouch. She described this event in a poem

Throughout this doom and gloom

There was a shining light

A story my brother told

From the Dreaming late one night

It gave me hope once again

The beauty that shone through

To share the stories with others

Telling them culturally, entertainingly

And true. ${ }^{21}$ 
It was not the content of the tale which inspired Pauline, but its form. From it Pauline began to develop a new view of her life in which her lost Aboriginal culture took a central role. She wrote as a diary entry:

In 1988 I moved to Sydney wishing to spend time with my natural family, and to try to overcome severe depression and start life anew. I went to the Eora Visual and Performing Arts Centre in Redfern and enrolled in the Performing Arts Course. From 1988 till 1991 I was a student and held a few jobs. I decided to become a performing artist and blues singer, a poet and writer as well as an Aboriginal Studies teacher and actor. ${ }^{22}$

By this time Pauline saw herself as a performer with the capacity to live a very different sort of life from that she had previously known. Another poem:

There was a girl who had a dream

That she was on the silver screen

Was seen by many near and far

As she became a famous star

She was followed everywhere

By fans who gave her googly stares

She thought it fun and it made her laugh

When people asked for her autograph. ${ }^{23}$

Pauline had found her calling and intended to become 'The Storyteller'. She believed that for thousands of years the Dreaming had been passed on in the oral tradition, and had produced 'an incredible culture and people'. This had not been done through books and electronic media, but through dance, music, art and storytelling. Pauline found what she thought were the best Dreaming stories that could be accepted by mainstream society. Her notes describe how she sought various elders and was granted permission by them to tell the stories. Her hope was that the stories would allow all those who listened to them the chance to finally understand and learn about Aboriginal culture.

Everyone in Australia knows the stories of Cinderella and Little Red Riding Hood, yet ... Australians do not know one Dreaming story. ${ }^{24}$

Pauline began to build a world view based on her perception of her culture. For her, the paradise that had existed in Australia for tens of thousands of years ended on 26 January 1788 when the Europeans arrived. This extract is taken from the lyrics of an opera which she co-wrote

Boorea:

Life is simple

Living in harmony with the land

Each day we hunt for food

And there is plenty of that 
The ancestors have provided well

Here the ancestors still dwell

In the animals

In the land

Listen, you can hear them.

Animals tell us. ${ }^{25}$

In yet another fragment of an unpublished story, she described what happened next:

Strangers came to the land. Ghosts, not spirits, who were flesh and blood. Not our ancestors but strangers from another land, far away. For the first time in memory, nightmares came alive. Death and destruction arrived: to the people, the animals, the plants and finally the land itself. It occurred in only a short time, a drop in a millennium. The wars left survivors amongst the rubble. No longer was the land maintained, no longer was there a possum in every tree. Many of the languages disappeared, and the lullabies going to the sky went silent. The Bora rings were empty, in their place came concrete and steel. The new laws are strange, ever changing and never the same. The strangers made their mark and never admitted to their fathers' sins. The idea of reconciliation is like the sparkling glass jewels on string bead necklaces and diseased blankets. Promises which remain to be carried out turn into lies. We are strong, though. We have been here since the beginning of time, and no matter what we will survive. The Dreaming is still here, waiting to be seen again. To be dreamt by the descendants of those from long ago. ${ }^{26}$

Her understanding of Aboriginal culture helped Pauline cope with the continuing depression she felt. She missed her mother and brother, and understood that they had bird totems, in which, whenever she saw them, she would find some solace, as the following writing fragment illustrates.

Crow! I know you are there looking over me. Helping by watching and calling. Mother crow, Brother crow. Stay with me always as I learn and grow, and when I trip and fall. Mother Crow, Brother Crow, looking after me. Give me the strength to stand again. When I despair, search for me, Mother Crow send Brother Crow into the sky. Search until you find me. I come back and there they are again. Come close so we can meet and see into each other's eyes. The spirit of the crow. My mother's totem. ${ }^{27}$

The personal salvation she found in her culture had the potential to save the entire planet, which, she believed, was in pressing need of saving. Her diary:

We have fifty years, and then it's going to happen. What? The end of the world - the earth - and we, the Aboriginal people, the first born, 
the custodians of the kind earth have to now spend all our energies to stop what is happening to the earth at the hands of 'man' and re-educate them and teach them the way. They are lost beyond reason and we are not to hate them or seek revenge, as what goes around comes around. But we have to teach them as you would a stubborn, AUTISTIC CHILD, because really, that's all they are. 'Lost, lonely and scared'. We have to 'Be Noahs, not Jonahs'. ${ }^{28}$

Her belief in culture became a source of great strength to her, even in what she described as manic phases, or highs. Her diary again:

My brain is working overtime, and I'm about to burst with ideas to really start getting ahead financially. As well as helping others get a start and to return to the community some of the things taken from them. So much happening, life is like a roller coaster. No complaints. Just hanging on, sometimes thrilled with pleasure, sometimes filled with fear, and wondering why. Once I saw life only in terms of a few hours, hoping to make it through the day. Now I plan for the years ahead. A future and career is here to stay. Dare I say, 'Things are GOOD!' ${ }^{29}$

As her reliance on her interpretation of Aboriginal culture deepened, so did her resolve to understand it and transmit it in a way she felt was appropriate.

Not a 'fad' for one generation but a long term cultural goal. Pauline tells the stories:

With respect

Accurately

In a culturally correct manner

Entertainingly ${ }^{30}$

Pauline saw that one way of changing the wider community's understanding of culture was by its transmission in a positive and socially useful form. As the new millennium approached, her ideas for a business enterprise began to emerge.

P.E. McLeod Enterprises Outline

1. Tanda Tents (markets)

2. Wirra Parru Foods (bush foods)

3. Parra Tours (cultural tours)

4. Kirka Marri Theatre (performers)

5. Nallawilli (storytelling)

6. Wobbly Wombats (children's shows)

7. Yanakirri Kurrumin Studios (animation)

8. Bangada Products (jewelry/ ornaments)

9. Gurung Products (baby items)

10. Yerthoappendi Products (educational) 
11. Thalangay Products (new inventions)

12. Watha Kampi Designs (fashion, clothing)

13. Writing Projects

14. Wirra Yarta (bush land farms) ${ }^{31}$

Aims and goals of P.E. McLeod Enterprises:

To set up fourteen companies by 2000 .

To employ

$75 \%$ Indigenous people

$25 \%$ non-Indigenous people

Logo: Promoting Indigenous, cultural and natural products. Developing new industries for the new millennium. Training the new masters of humanity, philosophy and the environment. ${ }^{32}$

Pauline was going to participate to make her culture not only relevant, but economically viable.

A mouse who never spoke

Just sat back and watched and learned.

And then one day, a change

Big way. No longer meek and mild.

Now I open my mouth and shout

With all my might

The mouse who never spoke

Opened her mouth

And everybody heard her shout. ${ }^{33}$

Pauline had now confirmed to herself not only the importance of culture, but the imperative of authenticity emerging only from Aboriginal people, whom she defined in her diary as being:

1. Must be a direct descendant of Aboriginal parents

2. Acknowledge self to be such and accept such

3. Before you can start to speak out as an Aboriginal person you must be accepted in the Aboriginal community

4. You must have experienced what an Aboriginal person faces on a daily basis, racism in all its ugliness.

Can one say they are Aboriginal if their direct line is a grandparent five generations ago, and they've not ever experienced racism or disadvantage because their family has followed the non-Aboriginal bloodline, until someone in recent times found a skeleton in the closet and decided to run with it? Does this make you an Aboriginal entitled to the resources available to Aboriginal communities and people? Interesting question, no easy answer. ${ }^{34}$ 
The debate on authorial integrity and authenticity was one which Pauline followed closely. She noted that:

As Aboriginal culture becomes very popular, every aspect of the culture if looked at, studied, used and abused. For example, the inappropriate use of language, (like the example of the cosmetics company in Victoria, 'Biamee's Cosmetics'). Or the use of our art, the didgeridoo, bush foods and medicines, and now our stories. The publication of Dreaming stories is still done mainly by non-Aboriginals who attempt to explain the stories in their own words. Some are done sensitively, others are totally misinterpreted, and even made up. A new trend in storytelling, especially the telling of Dreaming stories, is growing and the sad thing is that some of these new storytellers are making up stories and calling them Traditional Dreaming stories, or are just hearing or reading a story and liking it and telling it.

The rules of telling a Dreaming story are simple.

1. Find out where the story comes from and confirm.

2. Get permission from the elders of that region to tell the story.

3. With the elders, tell the story you want to tell and check whether your version is correct.

4. Learn the lessons and meanings behind the story.

5. When telling the story always acknowledge where it came from and the lessons and meanings behind it.

6. Never change the story or its meaning.

7. If you want to take it further, into publication, recording etc, get permission from the elders from where the story comes from.

Follow these rules to tell Dreaming stories correctly, culturally and for the next generation. ${ }^{35}$

Pauline's battle with what had by this time been diagnosed as bi-polar disorder continued to be the other defining component of her life, and she found herself again hospitalised for six months in $1997 .{ }^{36}$ At this time she was writing about alien abduction and the coming 'culling' of the human race which she believed would occur with the arrival of the new millennium. She still found strength in culture, and her position within the Aboriginal community, however, as another fragment illustrates:

I am THE storyteller. The custodian of stories, particularly those from the south east coast of Australia, NSW. I am a cultural elder. It is my job to keep an eye on the Dreamtime stories, particularly when they're being put into a modern context with modern materials, it is important they are done so correctly. I have the authority and of the power of the 
National Cultural Elders of this country. I have to do my job and do it well. ${ }^{37}$

By 2000 she came to believe that Aboriginal people had a different way of thinking, which she referred to in her diary as bi-lateral thought.

Considered rare in the modern world, the bi-lateral thinker is gifted in their ability to 'see the many' in the modern world. Western societies teach their citizens to become structured, one-thing-at-a time thinkers. Whereas in Indigenous cultures, such as in Aboriginal Australia, people are taught to think bi-laterally and see the many at the same time. The bi-lateral process has to be taught, as few people are born natural bi-lateral thinkers. The see the whole and not just the part requires teaching and training. To understand Aboriginal Australia you must become a bi-lateral thinker - which means you must be trained to do so. $^{38}$

Pauline's believed that the concept of bi-lateral thinking offered the capacity to change Australia's entire political structure.

The Democratic/communist/Royalist systems of control don't work. They all got it wrong from the start, and have tried to fix them instead of scrapping them. I sit and wonder why the masses keep voting for individuals they have never met to control their lives. You can't fix what is already broken with band-aids. A new political party, a new republic, based on the traditional Circle of Elders ideology. For the people, by the people. Environment, land, creatures, water, plants. Environmental industries. Eventual abandonment of land now used for criminals/ lawyers/ jails/ defence forces. A new judicial system. Peace officers are footmen, local. Lawmen are the ones who track down criminals and bring them back to the Circle of Elders for trial, and an appropriate punishment. The Circle both protects and defends. The crimes of individuals include the effects not just on victims, but on families and communities. ${ }^{39}$

\section{In conclusion}

Pauline's story is as complex as it is moving. With the benefit of her entire archive to choose from, I have selected two pieces of her writing to place near the end of her story.

The first is an affidavit prepared in conjunction with a legal case brought by her foster sister, harking back to the days so long before when Pauline had witnessed her being abused by the man they both knew as Pappa.

My memories of this time disappeared for several years and only in 1986 when I was reunited with my family did the memories come back. Around this time I rang my foster sister to find out if what I was 
remembering was true. She confirmed it all, although she swore me to secrecy over the foster father on the farm. I kept the secret as long as I could, but around 1996 I confronted Mrs F. about our past, with severe consequences. I am so sorry I was never able to stop what happened. As I was the eldest I was supposed to protect my brothers and sister. Sorry, sis. I am so sorry. ${ }^{40}$

Pauline's heart, known to be weak already after an attack of rheumatic fever when she was a child, stopped beating on 22 May 2003 - just eight days after she completed the affidavit.

The second of the two pieces I conclude Pauline's life story with is drawn from a video recording Pauline kept of her appearance on a panel discussion which aired on SBS Television.

Vivien Schenker: What do you believe happens to you when you die?

Pauline: I believe we go back into the land. As an Aboriginal person I believe that we go back into our totem, and we stay as our totem animal until we decide to get reborn and then we come back and live another life.

Vivien: What's going to happen to you?

Pauline: I'm going to go back to a black swan and hang around down the river for a while until I decide, 'Oh, it's a good time to be born again and see what it's like to be a human again'. But I'm going to be a black swan for a while. ${ }^{41}$

\section{References}

\section{Primary source}

The Pauline McLeod Archive (34 boxes of material which are held at the home of Michael McLeod, Pauline's brother.)

\section{Published sources}

Heiss, Anita M 2003, Dhuuluu Yala (To talk straight), Aboriginal Studies Press, Canberra.

Frisch, Michael $\mathrm{H}$ c1990, A shared authority: Essays on the craft and meaning of oral and public history, State University of New York Press, Albany.

Rainer, Tristine 1980 c1978, The new diary: How to use a journal for self guidance and expanded creativity, preface by Anais Nin, Imprint and Angus \& Robertson, London and Sydney. 


\section{ENDNOTES}

${ }^{1}$ McLeod: Diary extract, 1 January 1976. Pauline created many documents, of which a large proportion are undated or are fragments. All those presented in this document come from the collection held by her brothers. The archive is informal, and this is reflected in the structure of the citations for them. Some of Pauline's observations relate to events earlier in her life, so it should not be assumed that her comments were made contemporaneously with the events they describe.

2 Exploration of cultural content, authorial authority and other aspects of the compilation process not discussed in this paper are also part of my $\mathrm{PhD}$ research, and will be explored in greater detail in my forthcoming exegesis.

${ }^{3}$ Heiss 2003: 66.

4 Frisch 1990: 56.

${ }^{5}$ Pauline's notes from Rainer 1980 c1978.

6 McLeod: Diary extract, undated, possibly c1990.

7 Witchetty grubs - traditional 'bush tucker' of some Aboriginal people, which are actually insect larvae about four to six centimetres long.

8 McLeod: Play, The stolen one, c1988. This short play appears largely autobiographical, although most characters appear to have different names to those in Pauline's own life story. It appears that Pauline kept no program notes for it, so possibly it was never performed.

9 McLeod: Extract from short story, c1985.

${ }^{10}$ Report on State Ward, Youth and Community Services file extract, 29 April 1976.

11 McLeod: Statutory Declaration extract, 14 May 2003.

12 McLeod: Play, The stolen one extract, c1988.

13 McLeod: Diary extract, c1986.

14 McLeod: Fragment, c1986. Pauline recreated the conversation in script form.

15 McLeod: Poem, Mum extract, 17 August 2001.

16 McLeod: Diary extract, 16 October 1986.

17 McLeod: Extract from letter, April 1989.

18 McLeod: Diary extract, 4 April 1989.

19 McLeod: Diary extract, undated, c1990

${ }^{20}$ It is unclear whether these letters were ever sent, or if Pauline sent them but retained a copy of them.

21 McLeod: Poem extract, 17 August 2001.

22 McLeod: Diary extract, undated, c1990.

23 McLeod: Poem extract, c1990.

24 McLeod: Notes for a performance of 'Nallawilli', undated, c1990. 'Nallawilli' was a collection of stories told by Pauline and frequently performed, however it also referred to a production in the late 1980s of a series of stories and performances by Kooris in Theatre.

${ }^{25}$ Opera libretto, Garden of dreaming extract (1st draft written with Melle Amade), April 1996. The opera has never been performed.

${ }^{26}$ McLeod: Story fragment, undated, c1995.My understanding is that this is what Pauline believed and how she lived, or at least tried to live her life.

27 McLeod: Fragment, undated, c1995

28 McLeod: Diary extract, c1997.

29 McLeod: Diary extract, undated, c1998.

30 McLeod: Notes for a performance of 'Nallawilli', undated, c1990.

31 McLeod: Diary extract, 24 October 1997.

32 McLeod: Diary extract, undated, c1998.

33 McLeod: Poem, Mouse, undated, c1995.

34 McLeod: Diary extract, c1998.

35 McLeod: Fragment, c1998. It is worth noting that Pauline's earliest reference to telling Dreaming stories in the late 1980s had also included this caveat. 
36 Pauline's bi-polar disorder seemed to manifest itself more towards the late 1990s, at least it appeared to be diagnosed as such after this time, presumably prior to this she had assumed it was 'reactive' to the earlier events in her life. To what extent her condition was clinical and what extent it was reactive is impossible to say.

37 McLeod: Fragment, undated, c2000.

38 McLeod: Fragment, undated, c2000.

39 McLeod: Fragment, undated, c2000.

40 Statutory Declaration extract, 14 May 2003. Addendum to bottom of first draft of statutory declaration.

41 Transcript of SBS Interview regarding Religion extract with Pauline McLeod, Vivien Schenker (moderator), Jon Casimir (atheist) and Fiona Horne (witch), broadcast date unknown. 